University of Nebraska - Lincoln

DigitalCommons@University of Nebraska - Lincoln

Finance Department Faculty Publications

Finance Department

$1-1991$

\title{
The Effects of Airline Strikes on Struck and Nonstruck Carriers
}

Richard DeFusco

University of Nebraska-Lincoln, rdefusco1@unl.edu

Scott M. Fuess Jr.

University of Nebraska-Lincoln, SFUESS1@UNL.EDU

Follow this and additional works at: https://digitalcommons.unl.edu/financefacpub

Part of the Finance and Financial Management Commons

DeFusco, Richard and Fuess, Scott M. Jr., "The Effects of Airline Strikes on Struck and Nonstruck Carriers" (1991). Finance Department Faculty Publications. 8.

https://digitalcommons.unl.edu/financefacpub/8

This Article is brought to you for free and open access by the Finance Department at DigitalCommons@University of Nebraska - Lincoln. It has been accepted for inclusion in Finance Department Faculty Publications by an authorized administrator of DigitalCommons@University of Nebraska - Lincoln. 


\title{
THE EFFECTS OF AIRLINE STRIKES ON STRUCK AND NONSTRUCK CARRIERS
}

\author{
RICHARD A. DE FUSCO and SCOTT M. FUESS, JR.*
}

\begin{abstract}
This study provides new evidence on the industrywide impact of strikes by investigating how strikes have affected the values of struck and nonstruck airlines. Using stock market data for the years 1963-86, the authors show that most strikes adversely affected the value of struck airlines' stock but enhanced the stock value of nonstruck carriers. The results also show that strikes before October 1978, which marked the end of strict regulation of the industry and of the employers' mutual aid pact, had some effects different from those of strikes after that date.
\end{abstract}

\begin{abstract}
$\mathrm{A}_{\mathrm{N}}$ important conclusion of recent Astudies using stock market data to estimate the impact of unions on firms is that strikes have reduced the share value of struck firms. One question not yet answered, however, is whether strikes redistribute wealth within an industry. If one firm is selected for a strike while competing rivals remain in operation, the rivals may receive higher output prices and increase production. Thus, an effec-
\end{abstract}

\footnotetext{
* Richard DeFusco is Assistant Professor of Finance and Scott Fuess is Assistant Professor of Economics, both at the University of Nebraska, Lincoln. The authors thank James Fain, Gordon Karels, Martin Milkman, W. B. Nelson, Robert Sauer, and Thomas Zorn for helpful comments on earlier drafts of this paper, and Atiya Ahsan and Bongdae Choi for research assistance.

The authors also thank Jerrold Glass of the Airline Industrial Relations Conference, $1920 \mathrm{~N}$ Street, N.W., Washington, DC 20036, for providing the data on airline strikes, and Marion Mistrik of the Air Transport Association of America, 1709 New York Avenue N.W., Washington, DC 20006, for providing the same data. The data on share returns were obtained from the Center for Research in Security Prices of the University of Chicago. The computer programs used to generate the results presented in this paper are available from Richard DeFusco, Department of Finance, University of Nebraska, Lincoln, NE 68588.
}

tive strike targeted at one firm may reduce the value of that firm while increasing the value of nonstruck rivals.

To see if nonstruck rivals have benefited at the expense of struck firms, in this study we use stock market data covering the years 1963-86 to estimate the effects of airline strikes. The airline industry is especially well suited for an analysis of the intraindustry effects of strikes. Unions have selected individual airlines for strikes, leaving the remaining carriers free to operate. Because air travel cannot be produced in advance or stored in inventory, a strike of one airline may allow other carriers to benefit.

\section{The Intraindustry Effects of Strikes}

In a recent study, Carter, Hueth, Mamer, and Schmitz (CHMS) (1987) observed that a strike may not remove enough output to impose losses on producers. In fact, a strike may move an industry closer to the joint-profit maximizing outcome. Maloney, McCormick, and Tollison (1979) and Thompson (1980) have made similar points, arguing that strikes might create cartel-type profits. CHMS argued, as did Rees (1989:33), that 
an effective strike must inflict hardship on producers. Fuess (1990) showed that the effectiveness of strikes against individual firms in an industry depends on employers' inability to cooperate in resisting strikes. If a struck firm receives side payments from nonstruck rivals, then an effective strike must remove enough output from the targeted firm to reduce industry profit. If there are no side payments, then an effective strike need only reduce the struck firm's profit.

To estimate the economic costs of strikes, researchers have used stock market data and the event study methodology developed in financial economics. They have found not only that strikes reduce the value of struck firms, but also that the stock market has partially anticipated strikes. ${ }^{1}$ Although Becker and Olson (1986) found that strikes resulted in lower share values for struck firms, they noted (p. 433) that their study did not show how strikes affected nonstruck firms. ${ }^{2}$ Event study analysis, however, has been used to investigate the intraindustry impact of other firm-specific events. This approach has been taken to examine the effects of bank failures (Aharony and Swary 1983), automobile recalls (Jarrell and Peltzman 1985; Hoffer, Pruitt, and Riley 1988), and airline crashes (Borenstein and Zimmerman 1988; Chalk 1986, 1989; Karels 1989).

The airline industry provides a unique opportunity to estimate the intraindustry effects of strikes, since some strikes in that industry have hampered the operations of struck airlines while merely inducing nonstruck carriers to adjust their flight schedules. As media accounts of the recent Eastern Airlines strike indicate, other

\footnotetext{
${ }^{1}$ Among those studying the effects of strikes on equity share values are Becker and Olson (1986), Davidson, Worrell, and Garrison (1988), Greer, Martin, and Reusser (1980), Linneman and Spiller (1983), Neumann (1980), and Tracy (1988).

${ }^{2}$ Neumann and Reder (1984) reported that strikes have not affected industrywide production in U.S. manufacturing. They noted (p. 210 ) that this finding may reflect output reductions on the part of struck firms, with simultaneous output expansions by nonstruck firms.
}

carriers have apparently increased fares and carried more passengers in response to the developments at Eastern. ${ }^{3}$ In addition, since the deregulation of the industry in 1978 there has been a dramatic change in the operating and labor relations environments of airlines. This circumstance presents the chance to test whether the effects of strikes changed when the industry's environment changed.

\section{Estimating the Intraindustry Effects of Airline Strikes}

\section{Data and Sample Periods}

To analyze the stock market effects of strikes, we first gathered a sample of airline strikes. The strike data were obtained from the Airline Industrial Relations Conference (AIRCon) in the April 1987 report entitled "Strikes Under the Railway Labor Act, 1946-1986." This report lists the airlines and unions involved in strikes, as well as the beginning and ending dates of strikes. A copy of the same report was also provided by the Air Transport Association of America. To be included in our strike sample, the common stock of the struck airline had to be listed on the New York or American stock exchange and also had to have daily stock returns available on the University of Chicago's Center for Research in Security Prices (CRSP) daily returns file. Because daily data are available from CRSP only since July 2, 1962, our strike sample is restricted to 1963-86.

Labor relations for airlines are governed by the Railway Labor Act. Airlines operated in two distinct environments over the 1963-86 period. Prior to October 1978 the industry was heavily regulated. The Airline Deregulation Act, enacted on October 24, 1978, freed airlines to adjust domestic fares and routes. Deregulation also affected the airline industrial relations environment. ${ }^{4}$ Specifically, there was a

\footnotetext{
${ }^{3}$ Articles by Nomani (1989) and Valente (1989) are among those supporting this point; also see U.S News and World Report (1989).

${ }^{4}$ For surveys and reviews of airline labor relations-including discussions of various effects of
} 
dramatic change in the ability of nonstruck carriers to make side payments to struck airlines. From 1958 through 1978, some airlines participated in a mutual aid pact (MAP), which provided transfers from nonstruck to struck carriers. During the later years of the pact, 1962-78, struck airlines received $25 \%-50 \%$ of their normal air transport operating expenses through MAP funding. Enactment of the deregulation legislation effectively eliminated the pact. 5

Given the different operating and labor relations environments, we partition the strike sample into the mutual aid-regulation period, January 1963-October 1978, and the non-mutual aid-deregulation period, October 1978-December 1986. For each period we examine the performance of a "struck" portfolio and a "nonstruck" portfolio. Over the 1963-78 period there were 31 strike events at MAP member airlines for which stock market data are available. The "struck" portfolio thus contains 31 observations. For each strike in this period, the "nonstruck" portfolio contains nonstruck MAP members. There are 209 observations in the "nonstruck" portfolio. Pact membership information is taken from Unterberger and Koziara (1980).

During the non-mutual aid-deregulation period, there were 12 strike events at listed airlines that had belonged to MAP. For this period the "nonstruck" portfolio contains nonstruck airlines that had belonged to MAP. Two strike events in this

deregulation on collective bargaining - see Cappelli (1987), Curtin (1986), Hendricks, Feuille, and Szerszen (1980), Kahn (1980), Northrup (1971, 1983), and Thornicroft (1989), as well as the collections of papers edited by McKelvey (1988) and Rehmus (1977). A sizable literature has emerged on the various effects of airline deregulation. Among those presenting reviews and citations are Bailey, Graham, and Kaplan (1985) and Moore (1986).

${ }^{5}$ On the airlines' mutual aid pact-including discussions of the airlines participating in the pact, descriptions of how funds were paid into the pact and paid out during strikes, and lists of the dollar amounts transferred from nonstruck to struck airlines-see Cappelli (1987), Kahn (1980), Northrup (1977), and Unterberger and Koziara (1975, 1977, 1980). period are associated with Continental's 1983 bankruptcy, imposition of wage and work rule changes, and reorganization. ${ }^{6}$ The strikes were called off in 1985 , when the union members returned to work without settlements. Altogether, the airline was struck for a period of 765 days. To prevent Continental's unprecedented strike-bankruptcy episode from contaminating our results, we exclude Continental's strikes of 1983-85 from the "struck" portfolio for the 1978-86 period. The Continental case is analyzed separately.

An essential requirement of conventional event study methodology is "clean" event windows. Because we examine strike events over long intervals, it is important to exclude overlapping events. Our construction of the "nonstruck" portfolio thus excludes airlines experiencing overlapping strikes. To be more specific, if airline $A$ is struck on day 0 , then this event is included in the "struck" portfolio. We then construct intervals beginning 60 days prior to the strike announcement and ending 30 days after settlement. If, during A's strike interval, airline $B$ experiences a strike, then an overlapping strike has occurred, and airline $B$ is excluded from the "nonstruck" portfolio for the event period of airline A's strike. Similarly, the strike of airline $B$ is included as an event in the "struck" portfolio and airline $A$ is excluded from the "nonstruck" portfolio for that strike event. ${ }^{7}$

\section{Event Study Methodology}

To estimate the effects of strikes on struck and nonstruck airlines, we use stock market data to construct a measure of firm performance. Stock market data

\footnotetext{
${ }^{6}$ Among those discussing and recounting Continental's bankruptcy and strikes are Cappelli (1987) and Curtin (1986).

${ }^{7}$ As noted above, recent studies have examined the impact of plane crashes on airlines' share values. This research indicates that an airline experiences a reduction in share value following the occurrence of a crash. Thus, our construction of portfolios excludes airlines experiencing crashes during strike events. Information on crashes, including dates and airlines involved, can be found in Borenstein and Zimmerman (1988).
} 
allow an estimation of the normal, or expected, return to security $i$ on day $t$, $E\left(R_{i t}\right)$, in the absence of the event. The abnormal, or unexpected, return to the security, $A R_{i t}$, is the difference between its observed return, $R_{i t}$, and its expected return: $A R_{i t}=R_{i t}-E\left(R_{i t}\right)$.

The research hypotheses in this study are tested by employing the event study methodology described in Dodd and Warner (1983) and Brown and Warner (1985). A strike announcement date is denoted by $t=0$ and a strike settlement date is denoted by $t=$ SETTLE. Daily abnormal stock returns are estimated for each security over the interval $t=-60$ to $t=$ SETTLE +30 .

For a sample of $N$ events, the daily average (portfolio) abnormal return for each day $t, A R_{t}$, is computed by

$$
\begin{aligned}
A R_{t}= & (1 / N) \sum_{i=1}^{N}\left[R_{i t}-a_{i}-b_{i} R_{m t}\right], \\
t= & -60 \text { to } t=\text { SETTLE }+30,
\end{aligned}
$$

where $R_{i t}$ is the return to security $i$ on day $t$, and $R_{m t}$ is the return for the CRSP equally weighted market index on day $t$. The coefficients $a_{i}$ and $b_{i}$ are estimated from the market model regression $R_{i t}=a_{i}$ $+b_{i} R_{m t}+e_{i t}$ over the interval $t=-180$ to $t-81$.

To examine the intraindustry effects of strikes, we analyze the abnormal performance of the "struck" and "nonstruck" airline portfolios. If the effect of an event is distributed over time or if an event is partially anticipated, then the daily portfolio abnormal return may not accurately reflect the economic impact of the event. Airline strikes may be anticipated because the Railway Labor Act specifies a cooling off period of 30 days after the failure of mediation to achieve a settlement before a strike can begin. Consequently, we measure the cumulative impact of the strike with an average cumulative abnormal return.

An average cumulative abnormal return, CAR $\left(T_{1}, T_{2}\right)$, can be computed by summing the $A R_{t}$ 's over various intervals ( $t$ $=T_{1}$ to $t=T_{2}$ ). To isolate the "announcement" effects of strikes, we examine the portfolios' abnormal returns on the days immediately before and after the beginning of the strike. To examine the longer-term impact of strikes we examine the cumulative abnormal performance of the "struck" and "nonstruck" portfolios, starting as much as 60 days prior to the strike announcement and ending as much as 30 days after the strike's settlement. The expected value of $A R_{t}$ and CAR ( $T_{l}$, $T_{2}$ ) is zero in the absence of abnormal performance. The statistical significance of average abnormal returns and average cumulative abnormal returns is based on the average standardized abnormal return, $\mathrm{ASAR}_{t}$, and the average standardized cumulative abnormal return, $\operatorname{ASCAR}_{T_{1}}, T_{2}$, The standardized returns and standard normal Z-test statistics used in this study are presented in Chalk (1986) and Dodd and Warner (1983).

\section{The Effects of Strikes on Airlines' Share Returns}

We hypothesize that the effects of airline strikes occurring between January 1963 and October 1978 differed from the effects of airline strikes occurring after October 1978. During the earlier period, we expect that strikes had some adverse effect on the share returns of struck carriers, but an effect that was ameliorated by the presence of mutual aid and the regulation of routes. Also, since mutual aid payments were not explicitly linked to any wind fall benefits experienced by nonstruck carriers, but were tied to the normal operating expenses of the struck airlines, nonstruck carriers might have experienced a positive share price reaction.

During the later period, we hypothesize that airline strikes had much sharper effects on the share returns of struck carriers, because airlines' routes and fares were not regulated and there was no mutual strike aid. Without mutual aid and with deregulation making it easier than before for rival carriers to adjust routes and fares, we expect that an effective strike of an airline during the later period resulted in a negative market reaction for that airline and a positive market reaction for the nonstruck carriers. 
Strike settlements may also affect airlines' share values. To the extent that the suspension of aid payments, new contract terms, and any lost demand affect struck airlines, settlements may result in negative abnormal returns for those airlines and positive abnormal returns for nonstruck carriers. If, as suggested by Tracy (1988:4), strikes are a "learning mechanism" and settlements convey new information about the output demand faced by firms, then settlements may result in positive abnormal returns. Finally, strike settlements may be seen by nonstruck airlines as a preview of their own upcoming bargaining agreements. This last point may be important in the context of this study, because the 197886 period partly corresponds to a period of cost-cutting and concession bargaining in the airline industry. ${ }^{8}$

\section{The Effects of Strikes on Struck and Nonstruck Airlines: 1978-86}

Our empirical analysis begins with an examination of the effects of airline strikes in the non-mutual aid-deregulation period. Ten strike events are analyzed. As panel A of Table 1 shows, the announcement of a strike resulted in a significant negative cumulative abnormal return for the "struck" portfolio. For the intervals immediately surrounding a strike announcement, $(-1,0)$ and $(-1,1)$, the struck airlines experienced a negative CAR ranging from $2.66 \%$ to $3.14 \%$. For the "nonstruck" portfolio, containing 121 observations, the announcement of a strike resulted in a significant positive cumulative abnormal return. For the intervals $(-2,0),(-1,0)$, and $(-3,2)$, the positive CAR ranged from $0.12 \%$ to $1.74 \%$ (see Table 1, panel B).

Because airline strikes may be partially anticipated, we examine cumulative abnormal returns for both the 30-day and

\footnotetext{
${ }^{8}$ On the stock market effects of concession bargaining, see Becker (1987) and Becker and Olson (1987). On concession bargaining in the airline industry, see Cappelli (1987) and Thornicroft (1989); also see the collection of essays edited by McKelvey (1988).
}

Table 1. Strikes and Cumulative Abnormal Returns: The Effects of Strikes of Major Air Carriers on a Portfolio of Struck Airlines and a Portfolio of Nonstruck Airlines, October

1978-December 1986.

\begin{tabular}{|c|c|c|}
\hline Interval ${ }^{\mathrm{a}}$ & Mean (\%) & $\begin{array}{c}\text { Z-Value } \\
\text { (Absolute } \\
\text { Value) }\end{array}$ \\
\hline \multicolumn{3}{|c|}{$\begin{array}{l}\text { A: Portfolio of Struck Air Carriers: } \\
\text { Strike Announcement Effects }(n=10)\end{array}$} \\
\hline $\begin{array}{l}\operatorname{CAR}(-1,0) \\
\operatorname{CAR}(-2,0) \\
\operatorname{CAR}(0,1) \\
\operatorname{CAR}(-1,1) \\
\operatorname{CAR}(-3,2)\end{array}$ & $\begin{array}{r}-2.66 \\
-0.61 \\
-1.75 \\
-3.14 \\
0.70\end{array}$ & $\begin{array}{l}2.33^{* *} \\
0.43 \\
1.53 \\
2.24^{* *} \\
0.35\end{array}$ \\
\hline \multicolumn{3}{|c|}{$\begin{array}{l}\text { B: Portfolio of Nonstruck Carriers: } \\
\text { Strike Announcement Effects }(n=121)\end{array}$} \\
\hline $\begin{array}{l}\operatorname{CAR}(-1,0) \\
\operatorname{CAR}(-2,0) \\
\operatorname{CAR}(0,1) \\
\operatorname{CAR}(-1,1) \\
\operatorname{CAR}(-3,2)\end{array}$ & $\begin{array}{r}0.12 \\
1.74 \\
-0.13 \\
0.01 \\
0.91\end{array}$ & $\begin{array}{l}1.68^{*} \\
4.52^{* *} \\
0.60 \\
1.00 \\
2.11^{* *}\end{array}$ \\
\hline \multicolumn{3}{|c|}{$\begin{array}{l}\text { C: Portfolio of Struck Air Carriers: } \\
\text { Strike Interval Effects }(n=10)\end{array}$} \\
\hline $\begin{array}{l}\operatorname{CAR}(-30,-1) \\
\operatorname{CAR}(-60,-1) \\
\operatorname{CAR}(-30, \text { SETTLE }-1) \\
\operatorname{CAR}(\text { SETTLE,SETTLE }+30) \\
\operatorname{CAR}(-30, \text { SETTLE }+30)\end{array}$ & $\begin{array}{r}2.08 \\
-6.76 \\
4.26 \\
0.83 \\
5.09\end{array}$ & $\begin{array}{l}0.45 \\
1.52 \\
0.53 \\
0.35 \\
0.14\end{array}$ \\
\hline \multicolumn{3}{|c|}{$\begin{array}{l}\text { D: Portfolio of Nonstruck Carriers: } \\
\text { Strike Interval Effects }(n=121)\end{array}$} \\
\hline $\begin{array}{l}\text { CAR }(-30,-1) \\
\text { CAR }(-60,-1) \\
\text { CAR }(-30, \text { SETTLE }-1) \\
\text { CAR(SETTLE,SETTLE + 30) } \\
\text { CAR }(-30, \text { SETTLE + 30) }\end{array}$ & $\begin{array}{r}-0.34 \\
1.29 \\
-2.18 \\
5.31 \\
3.13\end{array}$ & $\begin{array}{l}0.35 \\
1.22 \\
1.80^{*} \\
4.40^{* *} \\
1.51\end{array}$ \\
\hline
\end{tabular}

${ }^{a}$ Day 0 , the strike start date, and SETTLE, the settlement date, are reported by AIRCon in the April 1987 report "Strikes Under the Railway Labor Act, 1946-1986." The data on share returns were obtained from the Center for Research in Security Prices, University of Chicago.

* Significant at the .10 level; ** at the .05 level.

60-day intervals, $\operatorname{CAR}(-30,-1)$ and $\operatorname{CAR}(-60,-1)$, preceding a strike announcement. As indicated in panels $\mathrm{C}$ and $D$ of Table 1, there is no evidence of significant CARs for these intervals during the $1978-86$ period. ${ }^{9}$

\footnotetext{
${ }^{9}$ In their analysis of the effects of airline deregulation, Michel and Shaked (1984) reported that during the years of sharply higher oil prices, 1978-80, over long intervals almost all airlines
} 
Table 2. Continental's Strikes and Bankruptcy, 1983-1985: Selected Daily Abnormal Returns.

\begin{tabular}{llr}
\hline Date & Event & $\begin{array}{c}\text { Daily Abnormal } \\
\text { Return }^{\mathbf{b}}\end{array}$ \\
\hline Aug. 11, 1983 & Airline threatens to hire strike-breakers if machinists (IAM) strike & $-9.24 \%^{*}$ \\
Aug. 15, 1983 & Trading day after machinists strike & $3.57 \%$ \\
Sept. 14, 1983 & Airline offers workers 35\% stake in company in exchange & $17.98 \%^{* *}$ \\
& for \$150 million in concessions & $-22.94 \%^{* *}$ \\
Sept. 23, 1983 & Trading day before bankruptcy action & $13.57 \%^{* *}$ \\
Sept. 26, 1983 & Trading day after bankruptcy action & $26.19 \%^{* *}$ \\
Oct. 3, 1983 & Trading day after flight attendants (UFA) and pilots & $14.53 \%^{* *}$ \\
June 20,1984 & (ALPA) strike & $2.66 \%$ \\
Apr. 17, 1985 & Bankruptcy action upheld in court & $-0.33 \%$ \\
Sept. 16, 1985 & Pilots return to work without settlement
\end{tabular}

a Dates represent the stock market trading days associated with the events. Starting and ending dates of strikes are reported by AIRCon in the April 1987 report "Strikes Under the Railway Labor Act, 1946-1986." Other dates are reported in the Wall Street Journal Index for the years 1983, 1984, and 1985. The data on share returns were obtained from the Center for Research in Security Prices, University of Chicago.

${ }^{b}$ During the 100-day interval $(-180,-81)$ before the machinists' strike there is a break in Continental's return series (of approximately five months) associated with a change in the airline's listing from the New York to the American Stock Exchange. Market model parameters are therefore estimated with the most recently available 100 days of return data.

* Significant at the .10 level; ** at the .05 level.

The effects of a strike on share returns need not be confined to the days surrounding its announcement, but may occur over the strike's duration and after its settlement. As in Becker and Olson (1986), we analyze cumulative abnormal returns over the interval beginning 30 days prior to the announcement of a strike and ending 30 days after its settlement, CAR(-30, sETTLE + 30). To focus solely on the effects of a strike's duration, we analyze CAR $(-30$, SETtLe -1$)$. To identify any settlement effects, we analyze CAR (SETTLE, SETTLE +30 ). For the "struck" portfolio, as shown in panel $\mathrm{C}$ of Table 1, there are no significant CARs over any of these intervals. Nonstruck airlines, however, experienced a $5.31 \%$

experienced negative abnormal returns relative to the stock market. To account for the possible influence of higher oil prices on airlines, we excluded the four strikes that occurred during the two-year period October 1978-October 1980 and reestimated the abnormal returns for the strike intervals for the "struck" and "nonstruck" portfolios. Not surprisingly, exclusion of the oil-shock years yielded greater CAR values, but our basic conclusions regarding the effects of strikes on struck and nonstruck airlines were not affected. positive cumulative abnormal return over the interval (SETTLE, SETTLE +30 ). ${ }^{10}$

As noted above, the strikes beginning in 1983 at Continental are unique because they overlap the airline's bankruptcy and reorganization. Table 2 shows that the announcement in August 1983 of an impending machinists' strike, prior to the bankruptcy action, had resulted in a significant negative abnormal return. After its initial bankruptcy announcement, in September 1983, Continental's share value rose significantly. The company's share value continued to rise during the strikebankruptcy-reorganization episode. Suspension of the strikes, in 1985, had no significant impact on the airline's share value. Over the entire strike period, Continental experienced a cumulative abnormal return of more than $120 \%$. The strike-bankruptcy events appear to have

${ }^{10}$ To check for possible model misspecification, we also conducted CAR tests for the 30-day intervals $(-90,-61)$, and (SETTLE +31 , SETTLE +60$)$. We conducted these CAR tests for our estimates in both the $1963-78$ and $1978-86$ periods. Significant CARs during these intervals might suggest benchmark error and not the true market reaction. In all cases, the CARs for these intervals were not significantly different from zero. 
resulted in a transfer of wealth from the airline's employees to its shareholders."

The empirical results in Tables 1 and 2 indicate that, as hypothesized, most airline strikes resulted in significant intraindustry transfers during the years following deregulation and the elimination of mutual aid. Effective strikes resulted in negative abnormal returns for struck airlines and positive abnormal returns for nonstruck airlines. The ineffective strikes by Continental's employees, however, resulted only in a redistribution of wealth from Continental's employees to its shareholders.

The Effects of Strikes on Struck and Nonstruck Airlines: 1963-78

There are 31 strike events for the mutual aid-regulation period. For the "struck" portfolio (see Table 3, panel A), the onset of a strike resulted only in a marginally significant negative cumulative abnormal return for the $(-1,1)$ interval. In addition, the struck airlines did not experience a significantly negative CAR in the 30-day or 60-day prestrike intervals (panel C). For the "nonstruck" portfolio a significant CAR is not observed for strike announcements (Panel B), but a significantly positive cumulative abnormal return is observed in the prestrike intervals (panel D).

An analysis of the strike duration and settlement intervals shows that struck MAP members experienced a marginally significant negative CAR after strike settlements. As shown in panel C of Table 3, the "struck" portfolio had a $5.32 \%$ cumulative abnormal loss over the (SETTLE, SETTLE +30 ) interval. Nonstruck MAP members, however, experienced significantly positive CARs over the strike duration interval and settlement interval

\footnotetext{
${ }^{11}$ The short interval results reported in Table 1, panel A become insignificantly positive when we include the two Continental strike events. This result, however, can be attributed to the large abnormal return associated with the strike by pilots and flight attendants. The nonstruck results in panel $B$ do not change significantly.
}

Table 3. Strikes and Cumulative Abnormal Returns: The Effects of Strikes of Major Air Carriers on a Portfolio of Struck Airlines and a Portfolio of Nonstruck Airlines, January 1963-October 1978.

\begin{tabular}{lcc}
\hline & & $\begin{array}{c}\text { Z-Value } \\
\text { (Absolute } \\
\text { Interval }\end{array}$ \\
\hline
\end{tabular}

\begin{tabular}{lcc}
\hline & $\begin{array}{c}\text { A: Portfolio of Struck Members } \\
\text { of the Mutual Aid Pact: }\end{array}$ \\
Strike Announcement Effects $(n=31)$ \\
CAR $(-1,0)$ & -0.96 & 1.54 \\
CAR $(-2,0)$ & -1.13 & 1.51 \\
CAR $(0,1)$ & -0.93 & 1.05 \\
CAR $(-1,1)$ & -1.32 & $1.76^{*}$ \\
CAR $(-3,2)$ & -1.44 & 1.60 \\
5 & \\
4 \\
\multicolumn{4}{c}{ Strike Announcement Effects $(n=209)$} \\
CAR $(-1,0)$ & 0.04 & 1.06 \\
CAR $(-2,0)$ & -0.12 & 0.97 \\
CAR $(0,1)$ & -0.07 & 0.04 \\
CAR $(-1,1)$ & -0.04 & 0.63 \\
CAR $(-3,2)$ & -0.31 & 0.16
\end{tabular}

C: Portfolio of Struck Members of the Mutual Aid Pact: Strike Interval Effects $(n=31)$

$\begin{array}{lrl}\text { CAR }(-30,-1) & 1.42 & 0.74 \\ \text { CAR }(-60,-1) & 5.45 & 1.54 \\ \text { CAR }(-30, \text { SETTLE - 1) } & 3.79 & 1.02 \\ \text { CAR(SETTLE,SETTLE + 30) } & -5.32 & 1.85 * \\ \text { CAR }(-30, \text { SETTLE + 30) } & -1.53 & 0.26\end{array}$

D: Portfolio of Nonstruck Mutual Aid Pact Carriers: Strike Interval Effects $(n=209)$

\begin{tabular}{lrr} 
CAR $(-30,-1)$ & 2.44 & $3.48^{* *}$ \\
CAR $(-60,-1)$ & 3.02 & $3.48^{* *}$ \\
CAR $(-30$, SETTLE -1$)$ & 6.77 & $4.49^{* *}$ \\
CAR(SETTLE,SETTLE +30$)$ & 3.52 & $3.01 * *$ \\
CAR $(-30$, SETTLE + 30) & 10.29 & $5.09 * *$ \\
\hline
\end{tabular}

${ }^{a}$ Day 0 , the strike start date, and SETtLe, the settlement date, are reported by AIRCon in the April 1987 report "Strikes Under the Railway Labor Act, 1946-1986." The data on share returns were obtained from the Center for Research in Security Prices, University of Chicago.

* Significant at the .10 level; ** at the .05 level.

(panel D). The "nonstruck" portfolio had a $10.29 \%$ cumulative abnormal gain over the $(-30$, SETTLE +30$)$ interval, with a $6.77 \%$ cumulative abnormal gain over the $(-30$, SETTLE -1$)$ interval. 


\section{Comparing the Stock Market Effects of Airline Strikes}

The empirical results suggest that some of the effects of airline strikes on share returns in the mutual aid-regulation period, 1963-78, differed from those effects in the non-mutual aid-deregulation period, 1978-86. This finding may indicate that differences between the two periods in the industry's operating and labor relations environments affected the impact of strikes. To compare the results across the two periods, we perform difference-in-means t-tests.

The announcement of a strike benefited nonstruck airlines during the 1978-86 period, but not during the 1963-78 period $(\mathrm{t}=4.17$ for the difference in CAR $(-2,0))$. During the later period, the impact of the positive "announcement effect" appears to have dissipated over the course of strikes. In the early period, but not in the later period, nonstruck airlines gained during strikes $(t=6.82$ for CAR $(-30$, SETTLE -1$)$ and $t=1.88$ for CAR $(-30$, SETTLE + 30)). We conjecture that these results may reflect the influence of deregulation: the announcement of a strike signaled an opportunity for nonstruck carriers to gain, but only temporarily, as competition among the carriers reduced abnormal gains. Regulation, on the other hand, may have sheltered nonstruck carriers from fare and route competition, allowing them to gain as strikes continued. Finally, nonstruck airlines gained about equally in both periods when strikes were settled $(t=1.60$ for CAR (SETTLE, SETTLE + 30)).

In both periods, too, the negative effect of strike announcements on struck airlines was about the same $(\mathrm{t}=1.08$ for $\operatorname{CAR}(-1,1)$ and $t=1.26$ for $\operatorname{CAR}(-1,0)$, suggesting that the availability of mutual aid payments did not affect the impact of a strike announcement. ${ }^{12}$

\section{Conclusion}

This study extends the research on the industry-wide impact of strikes by examining for the first time the effects of strikes on the share values of both struck and nonstruck firms in an industry. The empirical evidence confirms that effective strikes in the airline industry have had significant distributive effects, resulting in negative abnormal performance for struck airlines but positive abnormal performance for nonstruck carriers. The results also suggest strongly that the major changes that occurred in the industry's environment in October 1978-the end of mutual aid and of strict regulationsignificantly altered the impact of a strike.

We would expect to find similar results in other industries in which unions have targeted individual firms for strikes while rival firms have remained in operation. To the extent that struck firms are able to produce and store output in advance of a strike, however - a tactic air carriers obviously cannot employ-we might observe smaller negative abnormal returns for struck firms and smaller positive abnormal returns for their nonstruck rivals. An examination of strikes in manufacturing or mining industries would therefore provide a particularly interesting followup to the present study.

\footnotetext{
12 Since the mutual aid years coincide with airline regulation whereas the non-mutual aid period coincides with deregulation, it is difficult to disentangle the effects of mutual aid from those of regulation. It has been noted by Hirsch (1969) and by Karper (1987) that mutual aid has been used in other industries, such as newspapers and tires. Examination of these other "strike aid" industries would provide an opportunity to test more precisely for the impact of mutual strike assistance.
}

\section{REFERENCES}

Aharony, Joseph, and Itzhak Swary. 1983. "Contagion Effects of Bank Failures: Evidence from Capital Markets." Journal of Business, Vol. 56, No. 3 (July), pp. 305-22.
Bailey, Elizabeth E., David R. Graham, and Daniel P. Kaplan. 1985. Deregulating the Airlines. Cambridge: MIT Press.

Becker, Brian E. 1987. "Concession Bargaining: The 
Impact on Shareholders' Equity." Industrial and Labor Relations Review, Vol. 40, No. 2 (January), pp. 268-79.

Becker, Brian E., and Craig A. Olson. 1987. "Labor Relations and Firm Performance." In Morris M. Kleiner, Richard N. Block, Myron Roomkin, and Sidney W. Salsburg, eds., Human Resources and the Performance of the Firm. Madison, Wis.: Industrial Relations Research Association, pp. 43-85. 1986. "The Impact of Strikes on Shareholder Equity." Industrial and Labor Relations Review, Vol. 39, No. 3 (April), pp. 425-38.

Borenstein, Severin, and Martin B. Zimmerman. 1988. "Market Incentives for Safe Commercial Airline Operation." American Economic Review, Vol. 78, No. 5 (December), pp. 913-35.

Brown, Stephen J., and Jerold B. Warner. 1985. "Using Daily Stock Returns: The Case of Event Studies." Journal of Financial Economics, Vol. 14, No. 1 (March), pp. 3-31.

Cappelli, Peter. 1987. "Airlines." In David B. Lipsky and Clifford B. Donn, eds., Collective Bargaining in American Industry: Contemporary Perspectives and Future Directions. Lexington, Mass.: Lexington Books, pp. 135-86.

Carter, Colin, Darrell L. Hueth, John Mamer, and Andrew Schmitz. 1987. "Agricultural Labor Strikes and Farmers' Income." Economic Inquiry, Vol. 25, No. 1 (January), pp. 121-33.

Chalk, Andrew. 1986. "Market Forces and Aircraft Safety: The Case of the DC-10." Economic Inquiry, Vol. 24, No. 1 (January), pp. 43-60.

1989. "Comment on Karels." Economic Inquiry, Vol. 27, No. 2 (April), pp. 355-56.

Curtin, William J. 1986. "Airline Deregulation and Labor Relations." Monthly Labor Review, Vol. 109, No. 6 (June), pp. 29-30.

Davidson, Wallace N. III, Dan L. Worrell, and Sharon H. Garrison. 1988. "Effect of Strike Activity on Firm Value." Academy of Management Journal, Vol. 31, No. 2 (June), pp. 387-94.

Dodd, Peter, and Jerold B. Warner. 1983. "On Corporate Governance: A Study of Proxy Contracts." Journal of Financial Economics, Vol. 11, No. 1-4 (April), pp. 401-38.

Fuess, Scott M., Jr. 1990. "Strike Strategies and the Minimum Effective Union." Journal of Labor Research, Vol. 11, No. 1 (Winter), pp. 59-72.

Greer, Charles R., Stanley A. Martin, and Ted A. Reusser. 1980. "The Effect of Strikes on Shareholder Returns." Journal of Labor Research, Vol. 1, No. 4 (Fall), pp. 217-29.

Hendricks, Wallace, Peter Feuille, and Carol Szerszen. 1980. "Regulation, Deregulation, and Collective Bargaining in Airlines." Industrial and Labor Relations Review, Vol. 34, No. 1 (October), pp. $67-81$.

Hirsch, John S. 1969. "Strike Insurance and Collective Bargaining." Industrial and Labor Relations Review, Vol. 2, No. 3 (April), pp. 399-415.

Hoffer, George E., Stephen W. Pruitt, and Robert J. Reilly. 1988. "The Impact of Product Recalls on the Wealth of Sellers: A Reexamination." Journal of
Political Economy, Vol. 96, No. 3 (June), pp. 663-70.

Jarrell, Gregg, and Sam Peltzman. 1985. "The Impact of Product Recalls on the Wealth of Sellers." Journal of Political Economy, Vol. 93, No. 3 (June), pp. 512-36.

Kahn, Mark L. 1980. "Airlines." In Gerald G. Somers, ed., Collective Bargaining: Contemporary American Experience. Madison, Wis.: Industrial Relations Research Association, pp. 315-72.

Karels, Gordon V. 1989. "Market Forces and Aircraft Safety: An Extension." Economic Inquiry, Vol. 27, No. 2 (April), pp. 345-54.

Karper, Mark D. 1987. "Tires." In Lipsky and Donn, pp. 79-101.

Linneman, Peter, and Pablo T. Spiller. 1983. "On Estimating Unions' Motives." Unpublished paper, University of Pennsylvania.

McKelvey, Jean T., ed. 1988. Cleared for Takeoff: Airline Labor Relations Since Deregulation. Ithaca, N.Y.: ILR Press.

Maloney, Michael T., Robert E. McCormick, and Robert D. Tollison. 1979. "Achieving Cartel Profits Through Unionization." Southern Economic Journal, Vol. 46, No. 2 (October), pp. 628-34.

Michel, Allen, and Israel Shaked. 1984. "Airline Performance Under Deregulation: The Shareholders' Perspective." Financial Management, Vol 13, No. 2 (Summer), pp. 5-14.

Moore, Thomas Gale. 1986. "U.S. Airline Deregulation: Its Effects on Passengers, Capital, and Labor." Journal of Law and Economics, Vol. 29, No. 1 (April), pp. 1-28.

Neumann, George R. 1980. "The Predictability of Strikes: Evidence from the Stock Market." Industrial and Labor Relations Review, Vol. 33, No. 4 (July), pp. 525-35.

Neumann, George R., and Melvin W. Reder. 1984. "Output and Strike Activity in U.S. Manufacturing: How Large Are the Losses?" Industrial and Labor Relations Review, Vol. 37, No. 2 (January), pp. 197-211.

Nomani, Asra Q. 1989. "But Pan Am Turns Situation to Its Benefit." Wall Street Journal, March 17 , p. B1.

Northrup, Herbert R. 1971. "The Railway Labor Act: A Critical Reappraisal." Industrial and Labor Relations Review, Vol. 25, No. 1 (October), pp. 3-31.

1977. "Airline Strike Insurance: A Study in Escalation. Comment." Industrial and Labor Relations Review, Vol. 30, No. 3 (April), pp. 364-72.

1983. "The New Employee-Relations Climate in Airlines." Industrial and Labor Relations Review, Vol. 36, No. 2 (January), pp. 167-81.

Rees, Albert. 1989. The Economics of Trade Unions, 3rd ed. Chicago: University of Chicago Press.

Rehmus, Charles M., ed. 1977. The Railway Labor Act at Fifty: Collective Bargaining in the Railroad and Airline Industries. Washington, D.C.: National Mediation Board.

Thompson, Earl A. 1980. "On Labor's Right to Strike." Economic Inquiry, Vol. 18, No. 4 (October), pp. 640-53. 
Thornicroft, Kenneth W. 1989. "Airline Deregulation and the Airline Labor Market," Journal of Labor Research, Vol. 10, No. 2 (Spring), pp. 163-81.

Tracy, Joseph. 1988. "Testing Strategic Bargaining Models Using Stock Market Data." Working Paper No. 2754, National Bureau of Economic Research.

Unterberger, S. Herbert, and Edward C. Koziara. 1975. "Airline Strike Insurance: A Study in Escalation." Industrial and Labor Relations Review, Vol. 29, No. 1 (October), pp. 26-45.
1977. "Reply." Industrial and Labor Relations Review, Vol. 30, No. 3 (April), pp. 373-79.

1980. "The Demise of Airline Strike Insurance." Industrial and Labor Relations Review, Vol. 34, No. 1 (October), pp. 82-89.

U.S. News and World Report. 1989. "Caught in Eastern's Slipstream." March 27, pp. 10, 12.

Valente, Judith. 1989. "Strike at Eastern Proves Boon for Rivals as They Get More Traffic." Wall Street Journal, March 8, p. A3.

Wall Street Journal Index. 1983, 1984, 1985. New York: Dow Jones \& Co. 